\title{
ONYCHOMYCOSIS CAUSED BY Scytalidium dimidiatum. REPORT OF TWO CASES. REVIEW OF THE TAXONOMY OF THE SYNANAMORPH AND ANAMORPH FORMS OF THIS COELOMYCETE
}

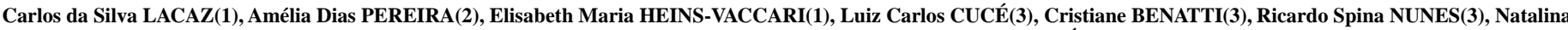
Takahashi de MELO(1), Roseli Santos de FREITAS-LEITE(1) \& Giovana Leticia HERNÁNDEZ-ARRIAGADA(1)

\begin{abstract}
SUMMARY
The authors report two cases of onychomycosis in the dystrophic form, one of them involving an HIV-positive patient, provoked by Scytalidium dimidiatum, previously called Scytalidium lignicola. The subject is reviewed from the taxonomic viewpoint, considering the anamorph Hendersonula toruloidea as a synonym of Nattrassia mangiferae, and having Scytalidium dimidiatum as the major synanamorph. According to many mycologists, Scytalidium hyalinum may be a separate species or a hyaline mutant of Scytalidium dimidiatum. Scytalidium lignicola Pesante 1957 was considered to be the type-species of the genus by ELLIS (1971) $)^{13}$ and later to be a "conidial state" of Hendersonula toruloidea by the same author, today known as Nattrassia mangiferae. The microorganism lives only on the roots of certain plants (mainly Platanus and Pinus). It produces pycnidia and is not considered to be a pathogen, although it is considered as a possible emerging agent capable of provoking opportunistic fungal lesions. The importance of this topic as one of the most outstanding in fungal taxonomy, so likely to be modified over time, as well as its interest in the field of dermatologic mycology, are emphasized.
\end{abstract}

KEYWORDS: Onychomycosis; Scytalidium dimidiatum; Nattrassia mangiferae.

\section{INTRODUCTION}

Skin infections simulating superficial or deep dermatophytoses, as well as cases of dystrophic onychomycosis caused by "nondermatophyte" fungi, are being reported with relative frequency, also in Brazil. Among the agents of these processes, the literature reports coelomycetes of the genus Scytalidium Pesante 1957, with the typespecies Scytalidium lignicola (currently called Scytalidium dimidiatum) having been isolated from wood (mainly Pinus and Platanus) as well as from various roots and from soil in England, India, Italy and Rhodesia (ELLIS, 1971) ${ }^{13}$. More recently, this species of demaceous or fuliginous hyphomycete was found to be a synanamorph of Hendersonula toruloidea Nattrass, 1933 (anamorph) which produces pycnidia and which is currently considered to be Nattrassia mangiferae SUTTON \& DYKO, $1989^{34}$. Since systematics is a dynamic science, often subjected to personal preference, its evolution must be accompanied on the basis of the opinions of most contemporary mycologists, so that now Scytalidium dimidiatum (Penzig, 1887) Sutton et Dyko, 1981, having Torula dimidiata Penz, 1887 and Exosporina fawcetti Wilson, 1947 as synonymy, is the synanamorph form of Nattrassia mangiferae SUTTON \& DYKO, $1989^{34}$, replacing Hendersonula toruloidea Nattrass, 1933.

Scytalidium lignicola Pesante, 1957 has been perfectly described in the 1971 edition of the excellent book by ELLIS ${ }^{13}$ on "Demaceous hyphomycetes", but as early as in the $2^{\text {nd }}$ edition, of $1976^{14}$, it is considered as a "state" or synanamorph of Hendersonula toruloidea, with reference to the formation of pycnidia.

Some mycologists such as SIGLER et al. $(1997)^{31}$ have questioned whether the former Scytalidium lignicola has been really described as an agent of human lesions. HOOG \& GUARRO $(1995)^{17}$, when describing the genus Scytalidium, refer to its colonies as fungi with saprophytic species living on wood and plants in general. According to ROEIJMANS et al. $(1997)^{30}$, melanin synthesis can be blocked in some cases, with the formation of hyaline colonies. This mutant is known as Scytalidium hyalinum CAMPBELL \& MULDER, $(1977)^{6}$ and is characterized by hyaline arthroconidia, as opposed to Scytalidium infestans, which is characterized by grayish conidia.

HOOG \& GUARRO (1995) ${ }^{17}$ consider Scytalidium japonicum to be a synanamorph of Nattrassia mangiferae, with no reference to Scytalidium lignicola, Pesante, 1957. S. japonicum Udagawa, 1986 forms rapidly growing grayish colonies with hyaline to brown hyphae and hyaline and cylindrical arthroconidia almost always pigmented, and has been isolated from cattle with bronchiolitis. Scytalidium infestans, isolated by IWATSU et al. (1995) $)^{18}$ from a fish (Pseudocarans dentex) with systemic mycosis, produces grayish arthroconidia with smoothwalled hyaline and grayish hyphae.

SIGLER et al. $(1997)^{31}$, referring to three cases of nail and skin infection published in Brazil by COSTA et al. $(1988)^{8}$ and COSTA et al.

(1) Laboratório de Micologia Médica do Instituto de Medicina Tropical de São Paulo and LIM/53 HC FMUSP.

(2) Instituto Adolfo Lutz, São Paulo, SP, Brasil

(3) Clínica Dermatológica da Faculdade de Medicina da USP (Serviço do Prof. Evandro Rivitti), São Paulo, SP, Brasil.

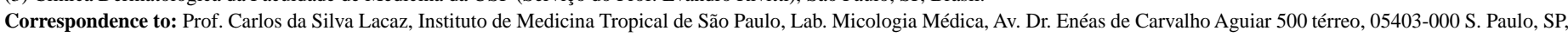
Brasil. 


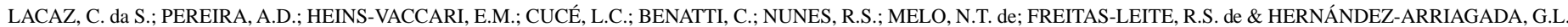
- Onychomycosis caused by Scytalidium dimidiatum. Report of two cases. Review of the taxonomy of the synanamorph and anamorph forms of this coelomycete. Rev. Inst. Med. trop. S. Paulo, 41 (5): 319-323, 1999.

$(1989)^{9}$, reported that in one of the "isolates" sent by COSTA there was formation of typical pycnidia, showing that the strain under study corresponds to Nattrassia mangiferae. The production of pycnidia occurs in special media based on cereals after 6 to 8 weeks of culture.

Thus, following the new orientation of a large number of taxonomists, we may consider the group of fungi indicated below:

Anamorph: Nattrassia maniferae (H. Sydow et Sydow) Sutton et Dyko, 1989.

Synonymy: Dothoriella mangiferae H. Sydow et Sydow, 1916; Hendersonula toruloidea Nattrass, 1933; Hendersonula cyprea Nattrass, 1937; Hendersonula aguthidis Young, 1948; Fusicoccum eucalypti da Camara, 1929.

Hendersonula was described by Spegazzini in 1880, with the species $H$. australis. In the genus Nattrassia the conidiogenic cells are phialids and in Hendersonula they are annelids. The conidia are holoblastic and smooth, eventually with 1 to 2 septa. Collars are absent in the conidiogenous cells. Toruloid vegetative cells (synanamorph) with arthroconidia are present.

Synanamorph: Scytalidium dimidiatum (Penz) Sutton et Dyko, 1989.
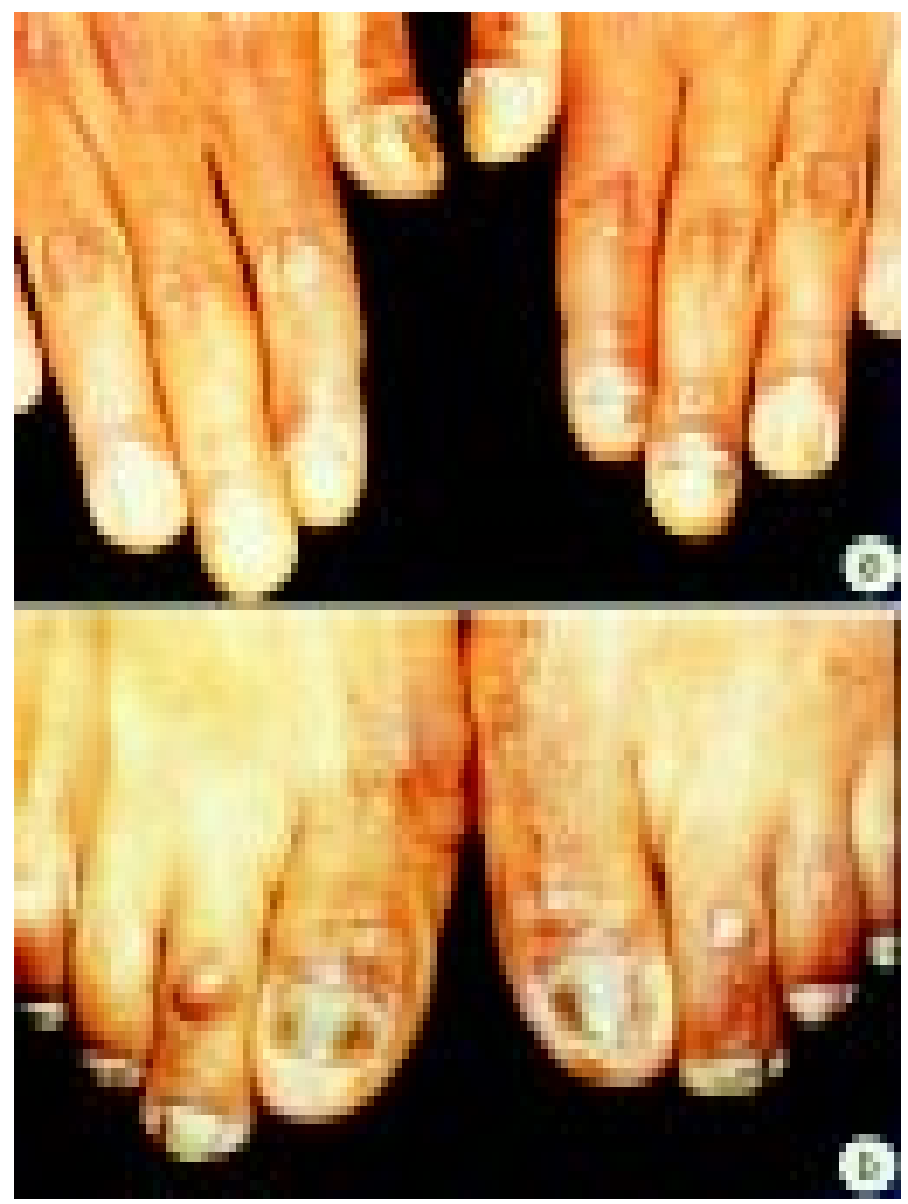

Fig. 1 - a) Fingers showing hyperkeratosis and nail dystrophy. Patient M.A. da S.P. (HIVpositive); b) Toes presenting hyperkeratosis and nail dystrophy (Patient M.L.G. de O.).
Synonymy: Torula dimidiata Penz, 1982; Exosporium fawcetti Wilson, 1947; Scytalidium lignicola Pesante, 1957. The fungus is detected on several plants, with superficial or immersed, branched, hyaline to grayish mycelium. Conidiophores are absent. Lageniform conidiogenous thickwalled cells and holoblastic, hyaline to grayish conidia, at times with a discrete collar, are observed.
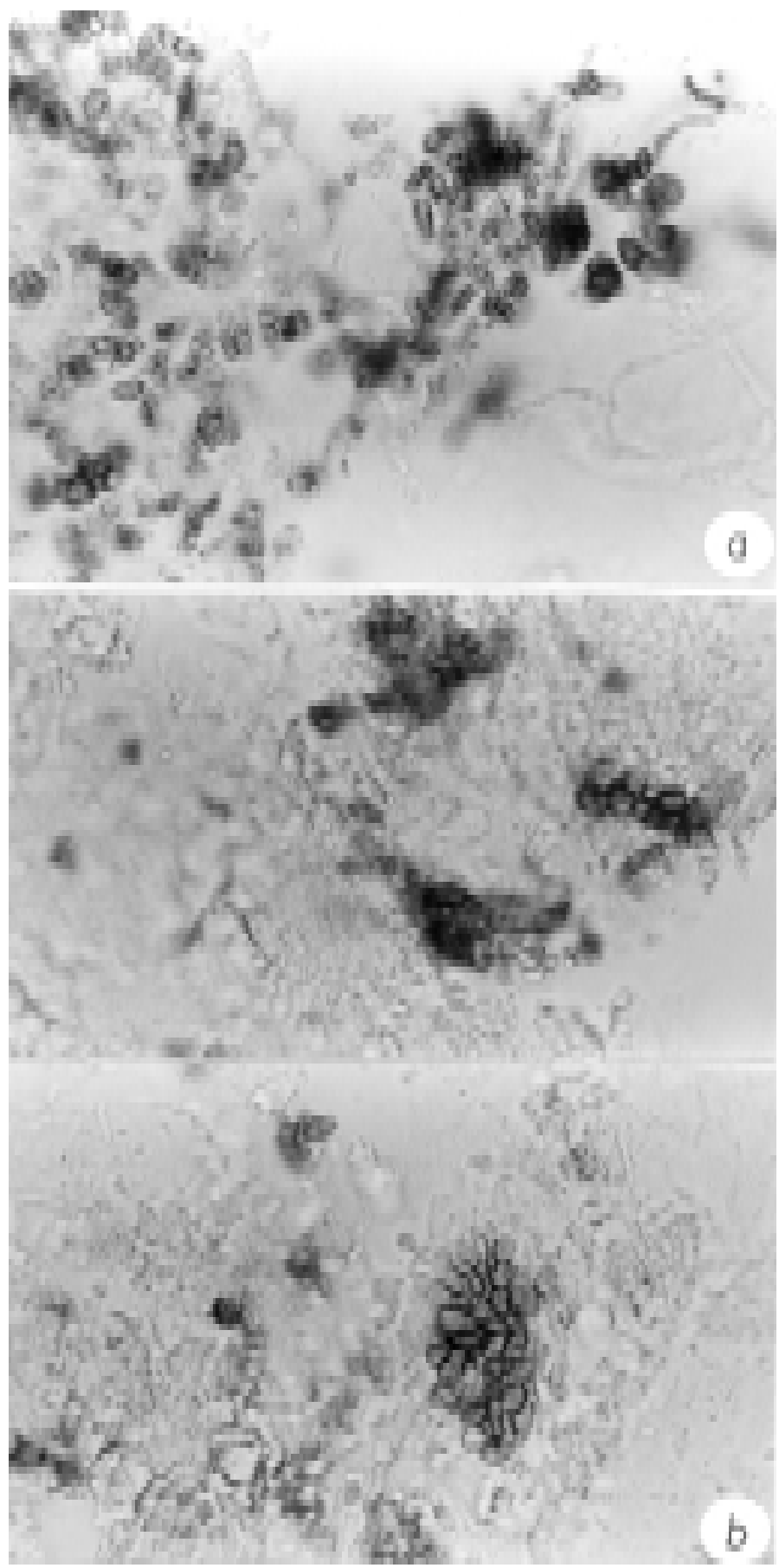

Fig. 2 - Direct examination of a nail scraping with $20 \% \mathrm{KOH}$ demonstrating arthroconidia and septate hyphae of ocher coloring (400x); a) patient M.A. da SP; b) patient M.L.G.de O. 


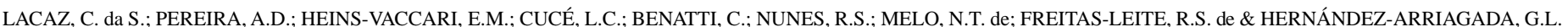

- Onychomycosis caused by Scytalidium dimidiatum. Report of two cases. Review of the taxonomy of the synanamorph and anamorph forms of this coelomycete. Rev. Inst. Med. trop. S. Paulo, 41 (5): 319-323, 1999.

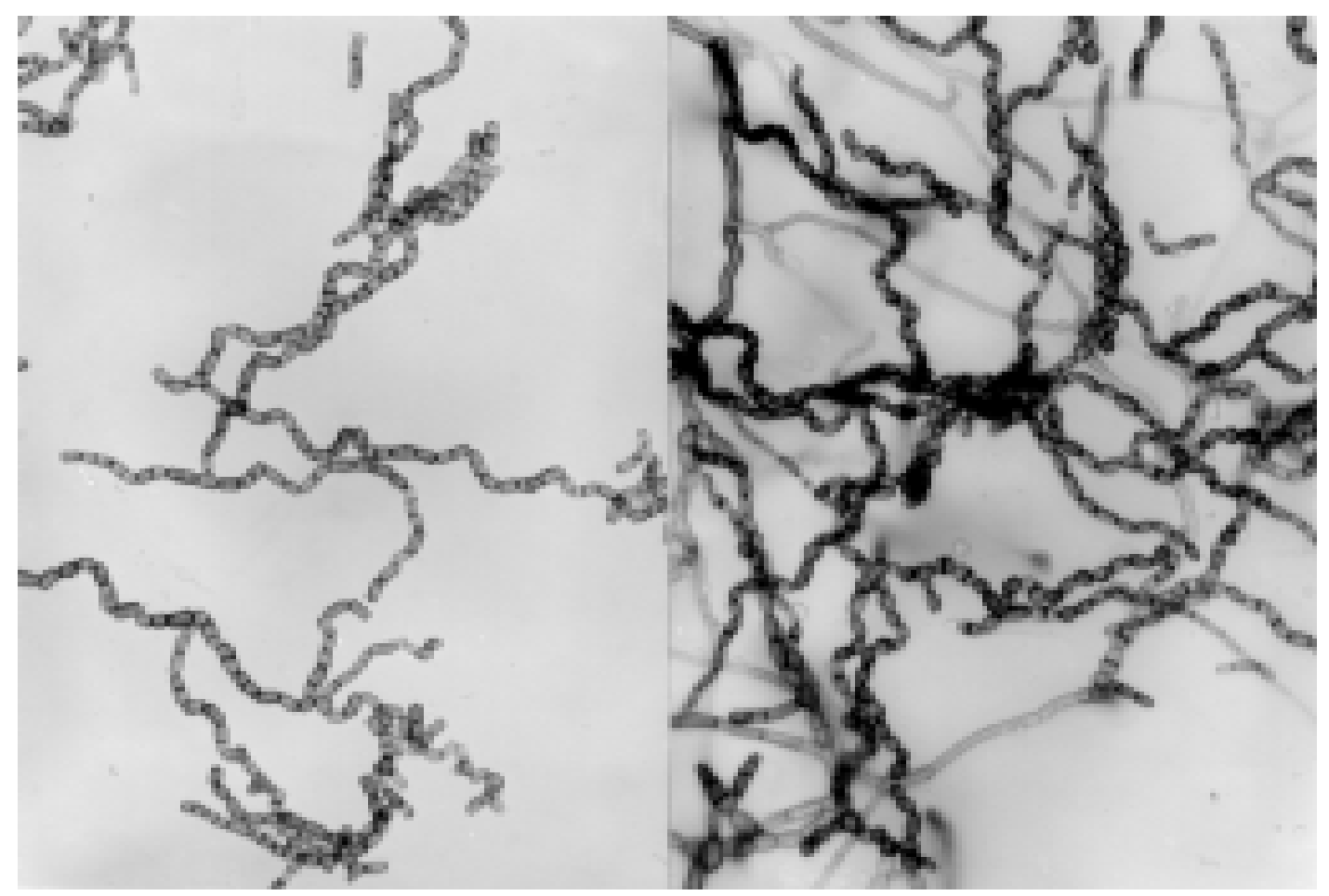

Fig. 3 - Scytalidium dimidiatum (isolated from patient M.L.G. de O.). Culture on potato agar on a slide showing chains of oblong arthroconidia of ocher coloring, some with clearly visible fine and black septa (400x).

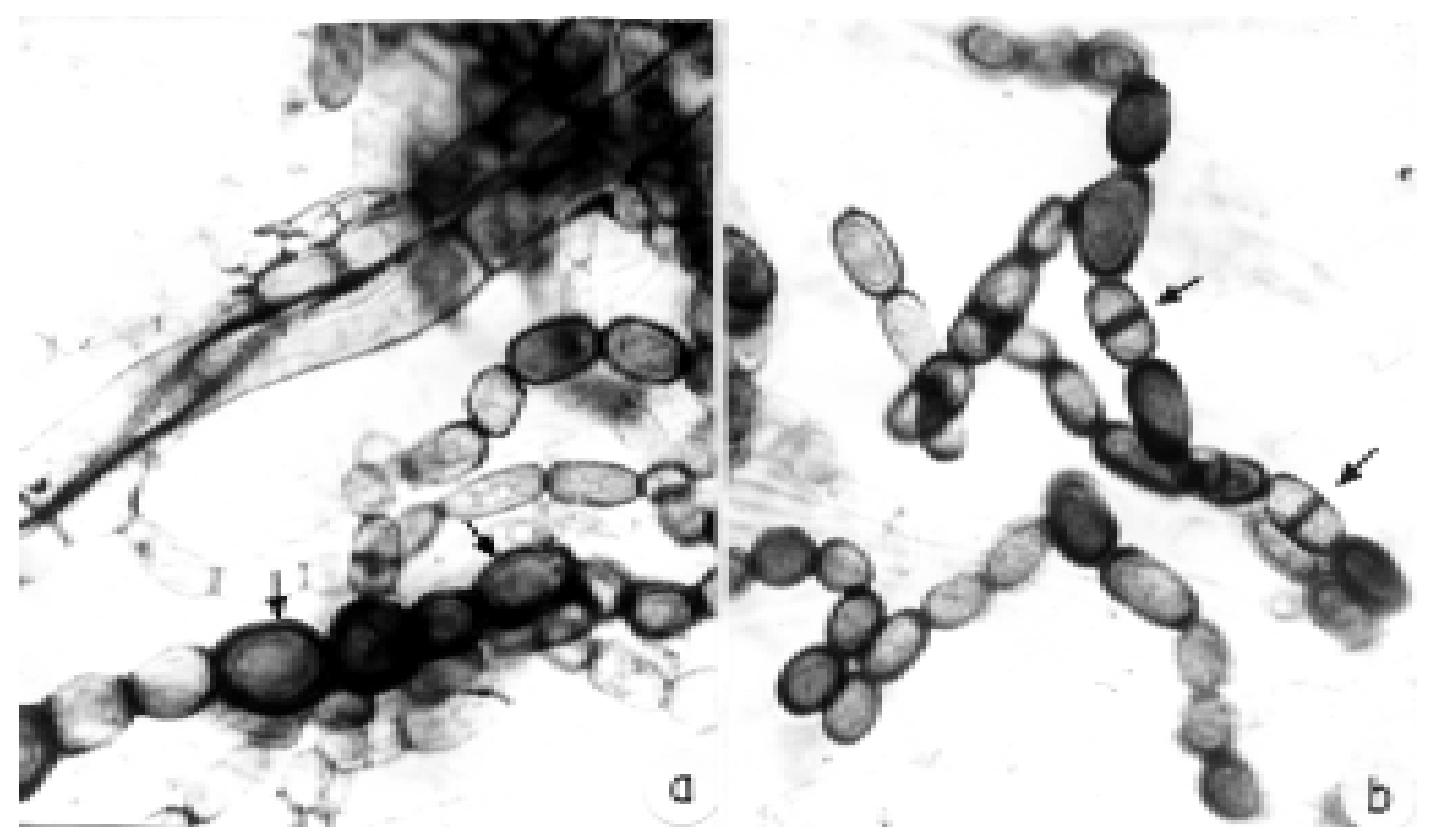

Fig. 4 - Scytalidium dimidiatum, previously considered to be Scytalidium lignicola, isolated from a case of interdigital cutaneous pheo-hyphomycosis. a) Unstained culture on potato agar dextrose of this hyphomycete. Note the wide ocher septate hypha and barrel-shaped dark brown doliform arthroconidia with a thick cell wall (arrows) among others that are smaller, oblong, light ocher in color and arranged in a chain (400x); b) oblong ocher arthroconidia truncated at each end, many of them devoid of septation and others (arrows) with a clearly visible dark septum (400x). Case reported by COSTA et al. (1988). 


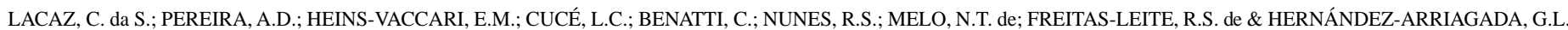
- Onychomycosis caused by Scytalidium dimidiatum. Report of two cases. Review of the taxonomy of the synanamorph and anamorph forms of this coelomycete. Rev. Inst. Med. trop. S. Paulo, 41 (5): 319-323, 1999.

Arthroconidia with a truncated base are present, oblong to doliform, grayish, with 1 septum. Globose, immersed, grayish to black pycnidia with a central ostiole are present.

\section{CASE REPORTS}

Case 1 - M.A. da S.P., HC registration number (São Paulo) 3158725C, a 38 year old HIV-positive male, presented lesions of the nails on the left and right hands in a dystrophic form (Fig. 1). Direct examination with $20 \% \mathrm{KOH}$ revealed hyaline hyphae and dematiae (Fig. 2).

Identification: Scytalidium dimidiatum. Treatment with itraconazole was instituted. He did not return for a scheduled visit.

Case 2 - M.L.G. de O., HC registration number (São Paulo) 3155630B, a 32 year old woman, presented lesions on the toes of 8 years duration. Dermatologic examination revealed lesions of dystrophic onychia on the nails of $1^{\text {st }}, 2^{\text {nd }}$ and $3^{\text {rd }}$ toes of the right foot and on the $2^{\text {nd }}$ and $3^{\text {rd }}$ toes of the left foot (Fig.1). Direct examination with 20\% KOH revealed toruloid hyphae of black coloring (Fig. 2).

Culture was positive for Scytalidium dimidiatum (Figs. 3 and 4 ). Local treatment with iodine alcohol and systemic with ketoconazole, 1 tablet a day, was instituted. The patient did not return for a scheduled visit.

\section{DISCUSSION}

In a chapter on non-dermatophytic fungi capable of causing nail and skin lesions simulating dermatophytoses, published in the excellent book by KANE et al. (1997) ${ }^{19}$, SUMMERBELL (1997) ${ }^{32}$ described Scytalidium dimidiatum as having dark or hyaline chains of arthroconidia, usually provoking desquamating lesions on the palms of the hands and on the soles of the feet in tropical and subtropical regions. SUMMERBELL $(1997)^{32}$ pointed out that in a survey carried out in Canada (SUMMERBELL et al., 1989) (33 $^{33}$ this fungus was responsible for $0.7 \%$ of the cases of onychomycosis and $0.2 \%$ of skin infections on the foot soles.

Scytalidium hyalinum is accepted as a valid species. According to SUMMERBELL (1997) $)^{32}$, S. lignicola is found in nature only on decomposing materials or in clinical material as a contaminant.

In addition to having been isolated from cutaneous lesions simulating dermatophytoses and onychomycoses ${ }^{15,16,20,25,26}$, Scytalidium dimidiatum and its anamorphs Nattrassia mangiferae $e^{7,29}$ and Scytalidium hyalinum ${ }^{27}$ have been isolated from cases of:

1 - Endophthalmitis (AL RAJHI et al., 1993)1.

2 - Disseminated infection in a granulocytopenic child (BENNE et al., $1993)^{5}$.

3 - Invasive or noninvasive subcutaneous lesions (DICKINSON et al., 1983 ${ }^{10}$; SIGLER et al., 199731; DHINDSA et al., 1998 ${ }^{11}$ ).

4 - Eumycetoma (DROUHET \& DUPONT, 1983) ${ }^{12}$.

5 - Lesions of the "verrucose dermatitis" type (MARILL et al., 197523; MARIAT et al., 1978 ${ }^{22}$ ).

6 - Maxillary necrosis in a diabetic patient (MIEGEVILLE et al., 1986) ${ }^{24}$ and post-traumatic infection (LEVI \& SMITH, 1994) ${ }^{21}$.
With respect to the treatment of Scytalidium infections, using the "corneofungimetry" process, ARRESE et al. (1998) $)^{2}$ observed that Scytalidium dimidiatum can grow on the corneal layer forming hyphae and that itraconazole can partially inhibit its growth when administered orally. SIGLER et al. (1997) ${ }^{31}$ observed in vitro susceptibility of Scytalidium dimidiatum to amphotericin B, itraconazole, 5-fluorcytocin, ketoconazole and myconazole.

HOOG \& GUARRO $(1995)^{17}$, when dealing with the genus Scytalidium, consider also Scytalidium infestans and Scytalidium japonicum, side by side with the hyalinum species. According to some mycologists, Scytalidium hyalinum is a mutant of Scytalidium dimidiatum, which usually causes hyperkeratotic lesions of hands and feet. According to PERRIN \& BARAN (1994) ${ }^{28}$, Scytalidium species provoke nail lesions, usually causing superficial and at times brownpigmented onychomycoses.

Total dystrophic lesions identical to those provoked by dermatophytes sometimes occur, as in the cases reported here (BARAN \& DAWBERS, 199433 BARAN et al., 19984).

\section{RESUMO}

Onicomicose por Scytalidium dimidiatum. Registro de dois casos. Revisão da taxonomia das formas sinanamorfas e anaforma deste celomiceto

Os Autores registraram dois casos de onicomicose sob forma distrófica, sendo um em paciente HIV-positivo, provocados pelo Scytalidium dimidiatum, no passado considerado como Scytalidium lignicola. Fazem uma revisão da matéria sob o ponto de vista taxonômico, considerado o anamorfo Hendersonula toruloidea como sinônimo de Nattrassia mangiferae, tendo como sinanamorfo principal o Scytalidium dimidiatum. Scytalidium hyalinum seria para muitos micologistas espécie à parte ou mutante hialina do Scytalidium dimidiatum. Scytalidium lignicola Pesante 1957, foi considerada por ELLIS (1971) ${ }^{13}$ como espécie-tipo do gênero e mais tarde $(1976)^{14}$, pelo mesmo Autor como "estado conidiano" de Hendersonula toruloidea, atualmente Nattrassia mangiferae. Vive somente em raízes de determinadas plantas (Pinus e Platamus, principalmente). Produz picnidios e até hoje não é considerado como agente patogênico, sem afastá-lo, todavia, como agente emergente, capaz de provocar lesões fúngicas oportunísticas. Salientam a importância do tema como um dos mais importantes na taxonomia fúngica, sujeita a tantas mudanças, bem como seu interesse, principalmente no campo da micologia dermatológica.

\section{ACKNOWLEDGMENT}

We are grateful to Creusa Paes Siqueira for typing the manuscript.

\section{REFERENCES}

1. AL-RAJHI, A.A.; AWAD, A.H.; AL-HEDAITHY, S.S.A.; FORSTER, R.K. \& CALDWELL, K.C. - Scytalidium dimidiatum fungal endophthalmitis. Brit. J. Ophthal., 77: 388-390, 1993.

2. ARRESE, J.E; DE DONCKER, P.; ODDS, F.C. \& PIÉRARD, G.E. - Reduction in the growth of non dermatophyte moulds by itraconazole: evaluation by corneofungimetry assay. Mycoses, 41: 461-465,1998. 


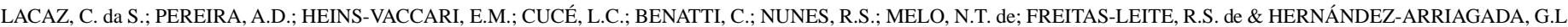
- Onychomycosis caused by Scytalidium dimidiatum. Report of two cases. Review of the taxonomy of the synanamorph and anamorph forms of this coelomycete. Rev. Inst. Med. trop. S. Paulo, 41 (5): 319-323, 1999.

3. BARAN, R. \& DAWBERS, R.P.R. - Diseases of the nails. 2.ed. Oxford, Blackwell Scientific Publications, 1994.

4. BARAN, R; HAY, R.J.; TOSTI, A. \& HANEKE, E. - A new classification of onychomycosis. Brit. J. Derm., 139: 567-571, 1998.

5. BENNE, C.A.; NEELEMAN, C.; BRUIN, M.; HOOG, G.S. de \& FLEER, A. Disseminating infection with Scytalidium dimidiatum in a granulocytopenic child. Europ. J. clin. Microbiol. infect. Dis., 12: 118-121, 1993.

6. CAMPBELL, C.K. \& MULDER, J.L. - Skin and nail infection by Scytalidium hyalinum sp. nov. Sabouraudia, 15: 161-166, 1977.

7. CAMPBELL, C.K.; KURWA, A.; ABDEL-AZIG, A.H.M. \& HODGSON, C. - Fungal infection of skin and nails by Hendersonula toruloidea. Brit. J. Derm., 89: 45-52, 1973 .

8. COSTA, A.R.; PIRES, M.C; PORTO, E. et al. - Interdigital cutaneous phaeohyphomycosis due to Scytalidium lignicola Pesante, 1957. A case report. Mycoses, 31: 604- 612, 1988

9. COSTA, E.F.; WANKE, B.; MONTEIRO, P.C. et al. - Cutaneous phaeohyphomycosis caused by Scytalidium lignicola. Report of the first three cases in Brazil. Mem. Inst. Oswaldo Cruz, 84: 135-136, 1989.

10. DICKINSON, M.G.; CLEARY, T.J.; SANDERSON, T. \& McGINNIS, M.R. - First case of subcutaneous phaeohyphomycosis caused by Scytalidium lignicola in a human. J. clin. Microbiol., 17: 155-158, 1983.

11. DHINDSA, M.K.; NAIDU, J. \& SINGH, S.M. - A case of subcutaneous infection in a patient with discoid lupus erytomatosus caused by a Scytalidium synanamorph of Nattrassia mangiferae, and its treatment. Med. Mycol., 36: 425-427, 1998.

12. DROUHET, E. \& DUPONT, B. - Laboratory and clinical assessment of ketoconazole in deep-seated mycoses. Amer. J. Med., 24: 30-47, 1983.

13. ELLIS, M.B. - Dematiaceous Hyphomycetes. Kew, Commonwealth Mycological Institute, 1971.

14. ELLIS, M.B. - More Dematiaceous Hyphomycetes. Kew, Commonwealth Mycological Institute, 1976

15. GENTLES, J.C. \& EVANS, E.G.V. - Infection of the feet and nails with Hendersonula toruloidea. Sabouraudia, 8: 72- 75, 1970.

16. GUGNANI, H.C. \& OYEKA, C.A. - Foot infections due to Hendersonula toruloidea and Scytalidium hyalinum in coal miners. J. med. vet. Mycol., 27: 169-179, 1989.

17. HOOG, G.S. de \& GUARRO, J. - Atlas of clinical Fungi. Baarn, Centraalbureau voor Schimmelcultures; Reus, Universitat Rovira i Virgili, 1995.

18. IWATSU, T.; UDAGAWA, S. \& HATAI, K. - Scytalidium infestans sp. nov. isolated from striped jack (Pseudocarax dentex) as a causal agent of systemic mycosis. Trans. Mycol. Soc. Jap., 31: 389-397, 1990. Apud: HOOG, G.S. de \& GUARRO, J., ed Atlas of clinical Fungi. Baarn, Centraalbureau voor Schimmelcultures; Reus, Universitat Rovira i Virgili, 1995. p. 640

19. KANE, J.; SUMMERBELL, R.; SIGLER, L.; KRADJEN, S. \& LAND, G. - Laboratory handbook of Dermatophytes. A clinical guide and laboratory manual of dermatophytes and other filamentous fungi from skin, hair, and nails. Belmont, Star Publishing Company, 1997.
20. KOMBILA, M.; MARTZ, M.; GOMEZ de DIAZ, M.; BIEVRE, C. de \& RICHARDLENOBLE, D. - Hendersonula toruloidea and an agent of mycotic foot infection in Gabon. J. med. vet. Mycol., 28: 215-223, 1990.

21. LEVI, M.E. \& SMITH, J.W. - Posttraumatic infection due to Scytalidium dimidiatum Clin. infect. Dis., 18: 127-128, 1994

22. MARIAT, F.; LIAUTAUD, B.; LIAUTAUD, M. \& MARILL, F.G. - Hendersonula toruloidea, agent d'une dermatite verruqueuse mycosique observée en Algérie. Sabouraudia, 16: 133-140, 1978 .

23. MARILL, F.G.; LIAUTAUD, M.; LIAUTAUD, B. \& MARIAT, F. - Dermatite verruqueuse mycosique due a un champignon dématié inhabitual. Discussion clinique et histopathologique. Bull. Soc. Path. exot., 4: 359-367, 1975.

24. MIEGEVILLE, M.; KREMPF, M.; LEGENT, F. et al. - Scytalidium forme arthrosporée de Hendersonula toruloidea isole d'une necrose de maxillaire gauche chez un diabetique français. Bull. Soc. franç. Mycol. med., 15: 427-432, 1986.

25. MOORE, M.K. - Hendersonula toruloidea and Scytalidium hyalinum infections in London, England. J. med. vet. Mycol., 24: 219-230, 1986.

26. MOORE, M.K. - Morphological and physiological studies of isolates of Hendersonula toruloidea Nattrass cultured from human skin and nail samples. J. med. vet. Mycol., 26: $25-39,1998$

27. MOORE, M.K.; DEL PALACIO-HERNANZ, A. \& LOPEZ-GOMEZ, S. - Scytalidium hyalinum infection diagnosed in Spain. J. med. vet. Mycol., 22: 243-245, 1984

28. PERRIN, C. \& BARAN, R. - Longitudinal melanonychia caused by Trichophyton rubrum Histochemical and ultrastructural study of two cases. J. Amer. Acad. Derm., 31: 311-316, 1994.

29. REVILLA, T.; MOORE, M.K.; JIMÉNEZ, C. et al. - Infección por Scytalidium dimidiatum diagnosticada en España. Rev. iberoamer. Micol., 9: 1-3, 1992.

30. ROEIJMANS, H.J. - Molecular taxonomy and GC/MS of metabolites of Scytalidium hyalinum and Nattrassia mangiferae (Hendersonula toruloidea). J. med. vet. Mycol. 35: 181-188, 1997.

31. SIGLER, L.; SUMMERBELL, R.C.; POOLE, L. et al. - Invasive Nattrassia mangiferae infections: case report, literature review, and therapeutic and taxonomic appraisal. J. clin. Microbiol., 35: 433-440, 1997.

32. SUMMERBELL, R.C. - Nondermatophytic molds causing dermatophytosis-like nail and skin infection. In: KANE, J.; SUMMERBELL, R.; KRAJDEN, S. \& LAND, G. Laboratory handbook of dermatophytes. A clinical guide and laboratory manual of dermatophytes and other filamentous fungi from skin, hair, and nails. Belmont, Star Publishing Company, 1997. p. 213-259.

33. SUMMERBELL, R.C.; KANE, J. \& KRAJDEN, S. - Onychomycosis, tinea pedis and tinea manuum caused by non-dermatophytic filamentous fungi. Mycoses, 32: 609$619,1989$.

34. SUTTON, B.C.B \& DYKO, J. - Revision of Hendersonula. Mycol. Res., 93: 466-488, 1989.

(1) Laboratório de Micologia Médica do Instituto de Medicina Tropical de São Paulo and LIM/53 HC FMUSP.

(2) Instituto Adolfo Lutz, São Paulo, SP, Brasil

(3) Clínica Dermatológica da Faculdade de Medicina da USP (Serviço do Prof. Evandro Rivitti), São Paulo, SP, Brasil.

Correspondence to: Prof. Carlos da Silva Lacaz, Instituto de Medicina Tropical de São Paulo, Lab. Micologia Médica, Av. Dr. Enéas de Carvalho Aguiar 500 térreo, $05403-$ 000 S. Paulo, SP, Brasil.

Received: 18 June 1999

Accepted: 15 September 1999

Fig. 1 - a) Fingers showing hyperkeratosis and nail dystrophy. Patient M.A. da S.P. (HIVpositive); b) Toes presenting hyperkeratosis and nail dystrophy (Patient M.L.G. de O.). 